\title{
Otto Koellreutter
}

\section{Die Geftaltung der deutfhen politi(d)en 追beit.}

Rede gehalten bei der Reidsgruindungsfeier Der $\mathfrak{U l n}_{\text {niverfitát }}$ Muindben

$$
\mathfrak{a m} \text { 18. Januar } 1934 .
$$

1934

Enünden, $\mathfrak{b e r l i n}$ und Eeipzig

I. Gahweiger Derlag (2ltthur Gellier) 
Drud von Dr. S. p. Datterer \& Cie, Sretingsmünden. 